\title{
A GLOBAL PICTURE OF EXTENDED PHARMACY SERVICES, PERCEPTIONS, AND BARRIERS TOWARD ITS PERFORMANCE: A SYSTEMATIC REVIEW
}

\author{
NAZRI NORDIN*, MOHAMED AZMI AHMAD HASSALI, AZMI SARRIFF
}

Department of Social and Administrative Pharmacy, School of Pharmaceutical Sciences, Universiti Sains Malaysia, 11800 Minden, Pulau Pinang, Malaysia. Email: nazri@i-raey.com

Received: 12 May 2017, Revised and Accepted: 31 July 2017

\section{ABSTRACT}

Objective: The aims of this review were to observe extended services performed in the community pharmacy settings, perceptions among community pharmacists (CPs), general practitioners (GPs), and customers of these extended services and barriers toward its performance.

Methods: A literature search was conducted, using Google Scholar as database, searching for full access texts. The inclusive texts fulfilled the inclusion criteria.

Results: A total of 22 texts had been systematically reviewed, noting a wide range of extended services performed in community pharmacy settings. Medication counseling or review and promoting health educations were noted as the most extended services performed. It is also noted that CPs indicated that these extended services could establish working relationship with other health-care professionals. However, it is noted that among the barriers toward extended services were lack of knowledge, skills, and time to perform.

Conclusion: As a conclusion, the community pharmacy practice is evolving, transforming into more patient-oriented even though there are some negative perceptions among the customers and GPs toward these extended services. Barriers to the performance of these extended services should be intervened.

Keywords: Extended roles, Community pharmacist, Perception, Barriers, Review.

(C) 2017 The Authors. Published by Innovare Academic Sciences Pvt Ltd. This is an open access article under the CC BY license (http://creativecommons. org/licenses/by/4. 0/) DOI: http://dx.doi.org/10.22159/ajpcr.2017.v10i11.19884

\section{INTRODUCTION}

Industrial revolutions have introduced synthetic organic chemistry knowledge as the source of modern medicine which its ingredients are compounded in huge bulks, sweeping away the age-old role of pharmacists to compound medicine for individual patients [1]. This scenario has influenced the pharmacy practice to evolve into dispensing readymade products [2]. Nevertheless, the role to dispense the products in some developed and developing countries is shared with the general practitioners (GPs) $[3,4]$ and pharmacy technicians (PTs) [5]. As a result, the role of community pharmacists (CPs) in the healthcare system like Malaysia is tremendously decreased until CPs has to sustain their existence through business-oriented service. Nowadays, CPs in Malaysia are also selling non-medical oriented products such as cosmetics, toiletries, and perfumes or else to fulfill the need of the local people. Such a practice is actually deteriorating the image as a professional health-care practitioner. In contrast, the CPs in developed countries like the United Kingdom and Australia are given the main right to distribute the products. In addition, they are collaborating with GPs to develop and monitor drug therapy regimen [6-8]. The scenario in the United Kingdom and Australia reflects some extended services can be performed in the community pharmacy settings. What are other extended services performing in the community pharmacy settings? What are the perceptions among CPs, GPs, and customers of these extended services? What are the barriers toward its performance? It is a rationale to explore other extended services performed in the community pharmacy settings because it can highlight some ideas for $\mathrm{CPs}$ in Malaysia to improve their current practice. Therefore, the aims of this review are to identify previous studies which addressing actual or potential extended services performed in the community pharmacy settings globally, perceptions among CPs, GPs, and customers of these extended roles as well as barriers to its performance.

\section{METHODS}

A systematic search of international literature reviews and studies was carried out using Google Scholar as an electronic database, searching for abstracts in English from January 2005 till January 2017. The search terms used were: Extended role; expanded pharmacy services; pharmacist care services; enhanced pharmacy services; private pharmacies; future services; public health; health-care systems; review; pharmacy; community pharmacy; CP; patient counseling; continuing pharmacy education (CPE); disease management; intervention; roles; health care. The abstracts were evaluated by the researcher, searching for relevant materials that fitted with the inclusion criteria as depicted in Table 1. The abstracts' concordance with the inclusion criteria was assessed for full texts. Then, another two researchers evaluated in detail the contents of each text, searching for materials that concordance with the criteria as depicted in Table 1. These inclusive texts were reflected in this review.

\section{RESULTS}

Literature search

A total of 4610 titles and abstracts were assessed against the inclusion criteria which depicted in Table 1, led to 111 titles and abstracts. The researcher assessed these shortlisted titles and abstracts for full access texts which led to 58 texts. Then, two researchers evaluated these texts to identify inclusion criteria which led to 22 texts out of 58 texts and these texts were reflected in this review. The flow of the searching process was depicted in Fig. 1.

\section{Description of the included texts}

The characteristic of the inclusive texts was depicted in Table 2. These texts were reflecting studies and article reviews conducted all around the world: Three in Europe (United Kingdom, Netherlands, Belgium), 
Table 1: Criteria for inclusion of studies in the review

\begin{tabular}{ll}
\hline Population & Community pharmacists, customers, and GPs \\
\hline Phenomenon of interest & $\begin{array}{l}\text { Extended services performed in community pharmacy settings outside Malaysia, perceptions among the } \\
\text { community pharmacists, customers, and GPs of these extended services and barriers toward its performance }\end{array}$ \\
Primary outcome measures & $\begin{array}{l}\text { The outcome measures but not restricted to it were } \\
\text { To describe extended services performed in community pharmacy settings outside Malaysia } \\
\text { To identify perceptions or attitudes among community pharmacists, customers, and GPs of these extended } \\
\text { services } \\
\text { To identify barriers toward the performance of these extended services }\end{array}$ \\
& Quantitative and qualitative studies as well as article reviews \\
Types of studies &
\end{tabular}

two in Africa (South Africa, Sudan), fourteen in Asia (Hong Kong, Japan, United Arab Emirates, Nepal, China, Pakistan, Jordan, Russia, Singapore), two in Australia, and one in Canada. The studies and article reviews were intervention studies $(n=2)$, survey studies $(n=5)$, survey with an interview session $(n=1)$, focus group discussion $(n=1)$, semistructured interviews $(n=3)$, and situation analysis based on other research papers and paper works $(n=10)$.

The inclusive texts as depicted in Table 2 were describing about the impact of extended services toward the pharmacy practice $(n=4)[6,7,20,22]$, perception among CPs and customers of extended services and barriers toward its performance $(n=4)[8,12,15,25]$, perception among CPs and other health-care providers of extended services $(n=3)[19,21,23]$, GPs' perception of extended services $(n=1)[16]$, the current pharmacy practice $(n=2)[9,10]$, the role of pharmacists in community pharmacy settings $(n=4)[13,14,17,18]$, and an advanced extended services $(n=4)[3,5,11,24]$.

In Singapore, the extended service performed by CPs was lagging from developed countries like the United Kingdom, Canada, and German [3]. CPs' knowledge and skills were underutilized due to lack of time, funding as well as a relationship with GPs. The GPs' dispensing role was still becoming the main issue to be intervened as it inhibited CPs from performing the philosophy of pharmaceutical care.

In Russia, CPs were in dilemma since their role to dispense medications was shared with other PTs [5]. As a result, the community pharmacy setting was not reflected as an ideal setting to perform extended services. Different clinical knowledge and skills between CPs and PTs might have potential to influence the performance of these extended services.

In the United Kingdom, under the enactment of Section 63 of the Health and Social Care Act 2001, the pharmacists were given the right to prescribe some exclusive medications and collaborate with doctors to develop a patient-specific clinical management plan [6]. However, the pharmacists have to attend an accredited supplementary prescribing course which was supervised by the Royal Pharmaceutical Society. Those who managed to complete the course would be awarded a practice certificate. Afterward, the pharmacists could perform their knowledge and skills in community pharmacy settings.

In Netherlands, CPs had performed medication review and cognitive behavior therapy services in the community pharmacy settings [7]. Both services were able to reduce numbers of drug-related problems (DRP) among discharge patients. As a result, GPs would like to collaborate with CPs to develop a drug therapy plan for their patients.

In Australia, CPs had performed a wide range of extended services in the community pharmacy settings $[8,11]$. Currently, CPs have been encouraged to be a prescribing pharmacist and serve the local population with a higher standard of practice.

In Jordan, CPs were focusing more on business-oriented than patientoriented services [9]. Furthermore, it was noted that the local law

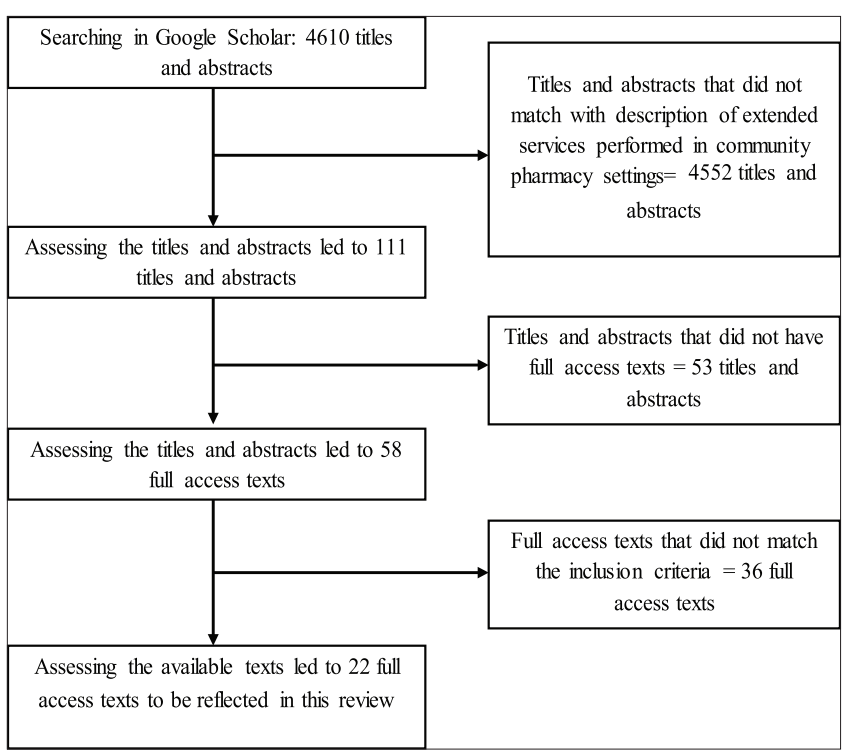

Fig. 1: Flow diagram of searching and inclusion criteria

was not strictly enforced allowing the people to have an access to all medications available in the community pharmacy settings including prescription drugs, except for narcotics and major tranquilizer. Therefore, the local universities had reviewed and improved their undergraduate program so that CPs could perform more patientoriented based services.

In China, the profession of CPs was promoted to be a primary healthcare provider [10]. As a result, the pharmaceutical care concept had been introduced for those CPs to perform this higher standard of practice in the community pharmacy settings. It was to ensure that its population could assess into a quality health-care services.

CPs in Canada had also performed a wide range of extended services in community pharmacy settings as depicted in Table 2 [12]. However, some barriers were noted as factors that inhibit the performance of these extended roles.

In South Africa, CPs were not allowed to dispense some most common medication from Schedule 3 of the South Africa Medicines Act 101 of 1965 [13]. As a result, the South African Pharmacy Council had introduced a Diploma in Pharmacy for Authorised Pharmacist Prescriber to teach the pharmacists to diagnose and treat their patients using the medications listed in the primarily health-care Essential Medicines List. The main purpose of this extended service was to improve the current pharmacy practice.

In the United Arab Emirates, CPs were not given the right image as a professional health-care practitioner. Therefore, the Health Authority Abu Dhabi was encouraging CPs to enhance their knowledge and skills 


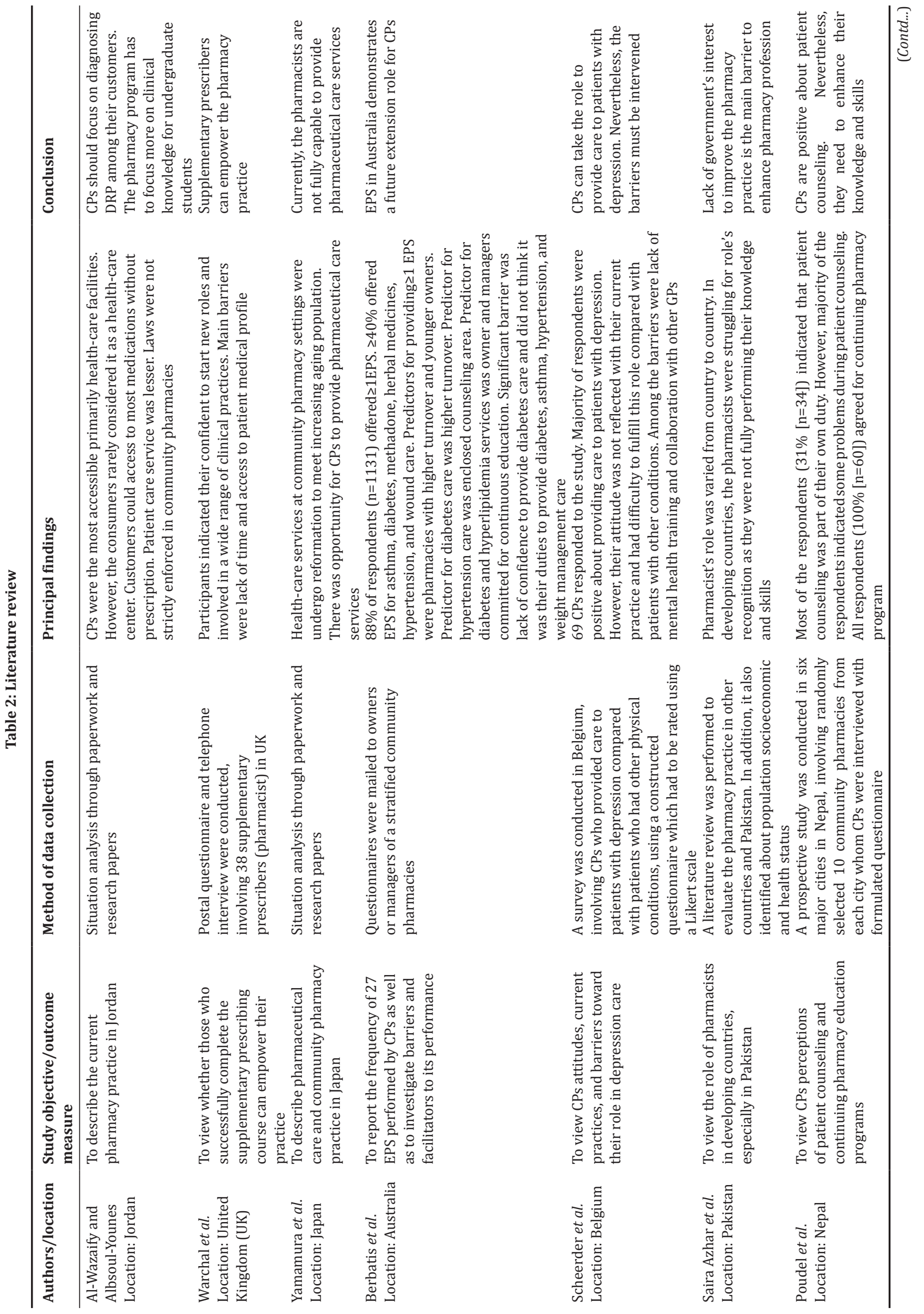




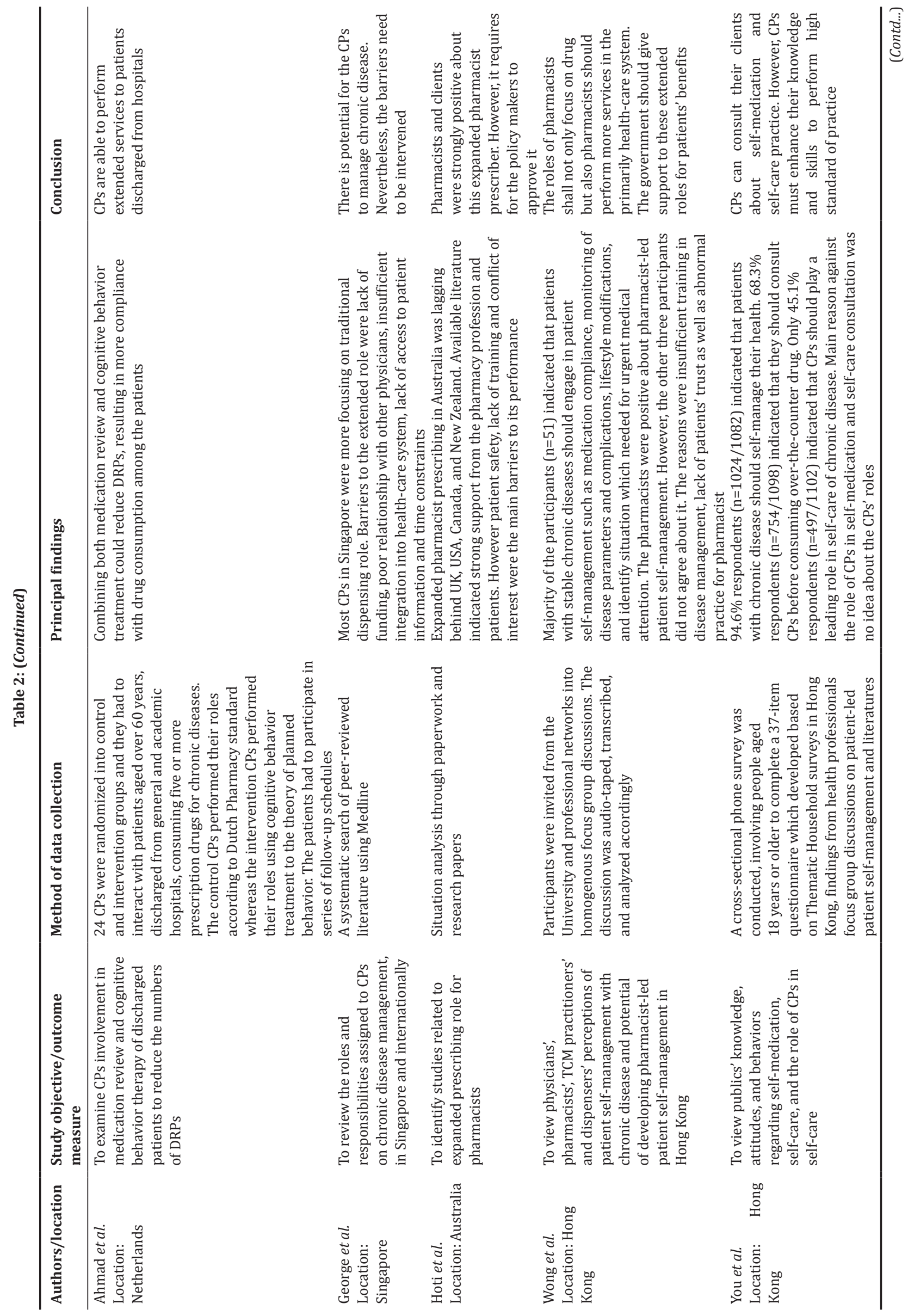




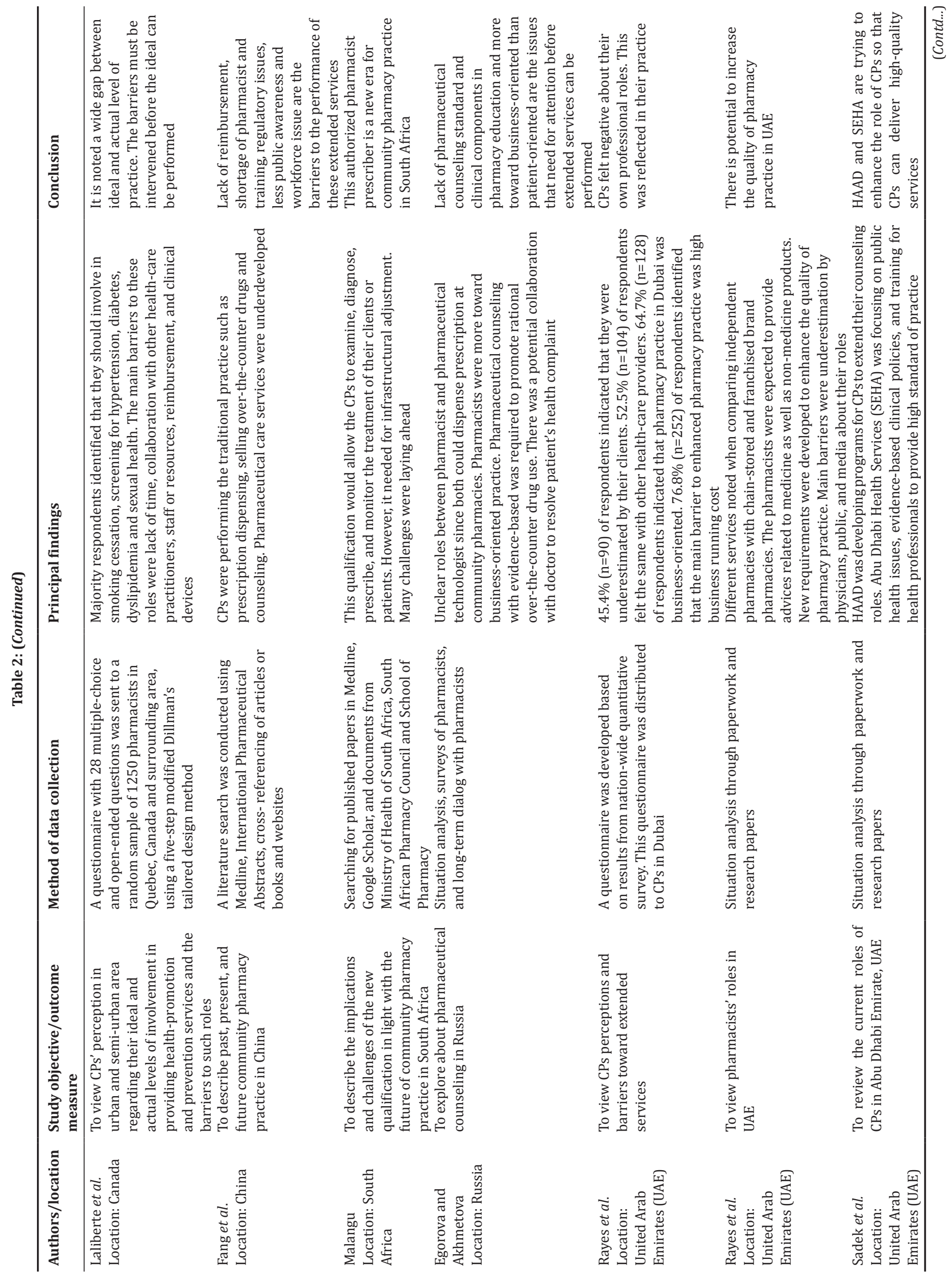




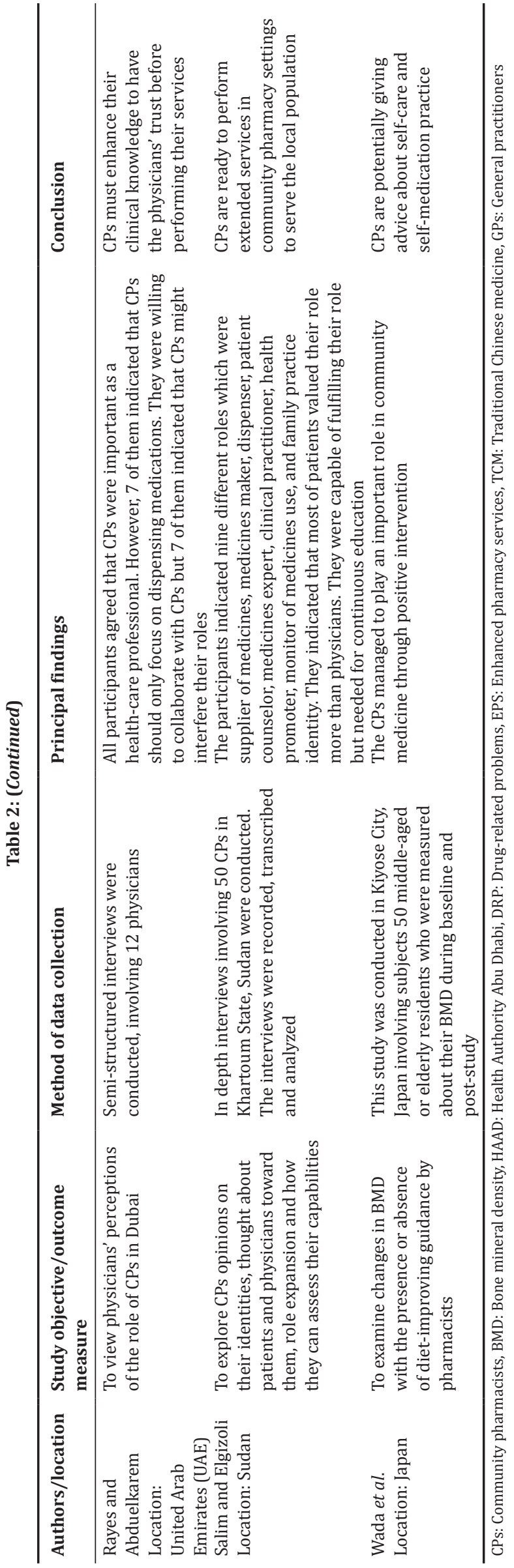

to improve their current practice and enhance their image as a healthcare practitioner in the eyes of GPs and customers [14,17]. GPs and customers perceived CPs as a businessman rather than a practitioner. Therefore, GPs did not want to collaborate with CPs to manage their patient's drug therapy regimen. As a result, it became a barrier to the performance of other extended services in community pharmacy settings $[15,16]$.

In Pakistan, pharmacists were not well recognized as a health-care practitioner in the health-care system [18]. As a result, CPs did not have the opportunity to collaborate with GPs to manage patient's drug therapy regimen. Therefore, Doctor of Pharmacy program had been introduced to enhance the image of the pharmacist as a competent health-care practitioner.

In Sudan, CPs believed that they could perform a wide range of extended services in the community pharmacy settings because they were knowledgeable in clinical knowledge [19]. Nevertheless, GPs were still underestimating their skills to perform the services. Therefore, CPs were encouraged to enhance their image as a health-care professional through advancing their knowledge and skills [19].

In Belgium, CPs had performed depression care service in the community pharmacy settings [20]. Nevertheless, this extended service had confronted with some barriers such as lack of knowledge and access to patient medical profile, absent of consultation room, and communication issue.

In Nepal, CPs were responsible for counseling their customers about medication use [21]. Therefore, they were required to attend an accredited CPE program to enhance their skills related to drug information [21].

Currently, In Japan, pharmaceutical care concept was not performed in community pharmacy settings [24]. Nevertheless, the Japan Pharmacists Education Centre was taking an initiative to educate CPs about the pharmaceutical care philosophy so that CPs could perform this philosophy in their current practice. It was also noted that CPs had performed an osteoporosis care service as an extended service in the community pharmacy setting to serve the elderly people [22].

In Hong Kong, CPs were encouraged to perform a pharmacist-led patient self-management service and act as a self-care advisor in community pharmacy settings $[23,25]$. However, other health-care professionals and customers indicated some negative perceptions of these extended services.

\section{Extended services}

Extended services performed in community pharmacy settings were depicted in Table 3. It was noted that medication counseling or review $(n=10)$ was the most performed in community pharmacy settings. CPs in Australia $(n=28)$ had performed a wide range of extended services in their community pharmacy settings, followed by CPs in the United Arab Emirates ( $n=17)$, Canada ( $n=12)$, Hong Kong ( $n=8)$, and China $(n=5)$.

\section{Perception of extended services}

The perceptions among CPs, GPs, and customers of the extended services were depicted in Table 4. It was noted that GPs perceived these extended services could establish a working relationship with CPs $(n=6)$ and this perception was the most noted in the review. It was also noted that the study in the United Kingdom $(n=14)$ indicated a wide range of perceptions among the participants of extended services, compared with other studies conducted in other countries. The perception among policy makers of the extended services was not noted in this review.

\section{Barriers to its performance}

Barriers to its performance were depicted in Table 5. Lack of knowledge or skills $(n=11)$ was the most noted in this review. A study in the 
Table 3: Details of country which indicated extended services

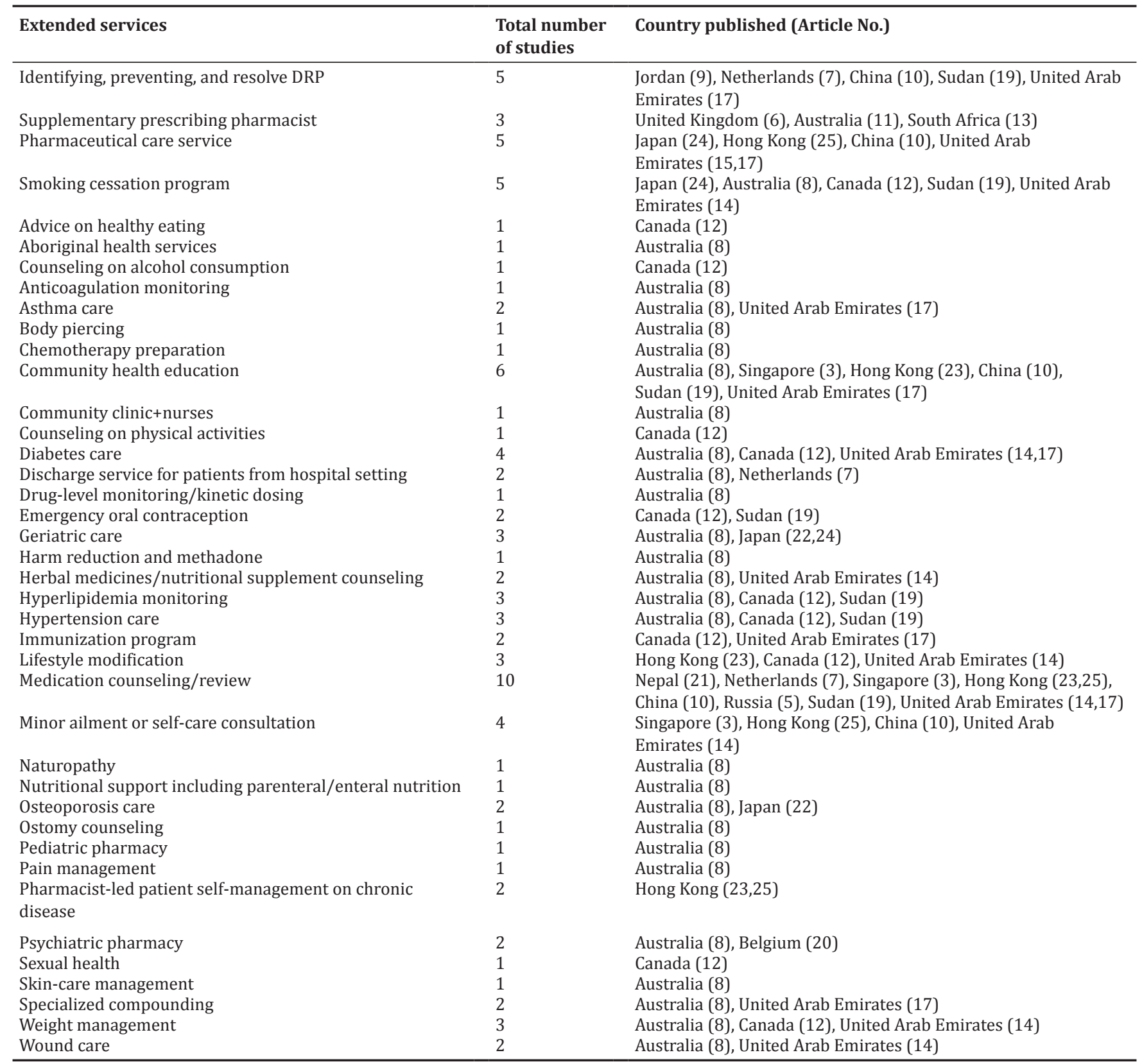

United Kingdom ( $\mathrm{n}=25)$ indicated more numbers of barriers, compared with other studies in other countries.

\section{DISCUSSION}

It is noted in this review a dramatically changing the age-old of pharmacist role as compounding practitioner to dispense readymade products toward a more prominent role in the health-care system. Undoubtedly, this scenario indicates demand among the local population toward the extended services [26] and requiring CPs to closely interacting with GPs and customers [27]. This interaction between CPs and GPs or customers is noted in Australia, South Africa, United Arab Emirates, Sudan, United Kingdom, and Hong Kong [6,11,13,16,19,23]. Undoubtedly, the interaction reflects a potential for CPs to perform the extraordinary task which is assessing patient-related information such as demographic data, medical, and medication information $[28,29]$. Nevertheless, it is noted a few barriers that inhibit this extended service. For example, it is noted that confidence or trust issues with
CPs are the barriers to its performance in the United Kingdom, United Arab Emirates, Belgium, Nepal, and Hong Kong [6,12,15,20,21,25]. Therefore, it is advisable to use the available social media such as blogs, Facebook, YouTube, Wikipedia, bulletin, and newspaper to educate the people [30] and GPs [31] about the potential of these extended services to improve patients' quality of life.

It is also noted that lack of knowledge or skills has become a barrier to the performance of extended services and noted in Australia $[8,11]$, Belgium [20], China [10], Japan [22], Nepal [21], Hong Kong [23], Canada [12], Russia [5], Sudan [19], and United Arab Emirates [14]. Nevertheless, this barrier can be intervened when CPs take an initiative to enhance their skills in varies therapeutic knowledge. For example, it is noted the Royal Pharmaceutical Society in the United Kingdom provides a training program for $\mathrm{CPs}$ to have skills to prescribe some supplementary medications to patients who are on other medications prescribed by GPs [6]. Other noted training programs for CPs are smoking cessation [32], anticoagulant program [33], and hypertension 
Table 4: Details of country which indicated perception of extended services

\begin{tabular}{|c|c|c|}
\hline Perception of extended services & $\begin{array}{l}\text { Total number } \\
\text { of studies }\end{array}$ & Country published (Article No.) \\
\hline $\begin{array}{l}\text { Patient rarely considers community pharmacies to be } \\
\text { health-care facilities }\end{array}$ & 1 & Jordan (9) \\
\hline Easing the burden of physicians' overloaded activities & 1 & Australia (8) \\
\hline Encouraged by the pharmacy associations & 2 & United Kingdom (6), Australia (11) \\
\hline Fulfilling the need of the government & 1 & United Kingdom (6) \\
\hline Shortage of physicians & 1 & United Kingdom (6) \\
\hline Financial reimbursement & 1 & United Kingdom (6) \\
\hline Performing existing skills & 5 & $\begin{array}{l}\text { United Kingdom (6), Nepal (21), Australia (11), South Africa (13), } \\
\text { Sudan (15) }\end{array}$ \\
\hline Taking a new challenge & 1 & United Kingdom (6) \\
\hline Promoting personal marketability & 1 & United Kingdom (6) \\
\hline $\begin{array}{l}\text { Taking greater responsibilities with their drug therapy } \\
\text { plan }\end{array}$ & 2 & United Kingdom (6), South Africa (13) \\
\hline Working relationship with other health-care professionals & 6 & $\begin{array}{l}\text { United Kingdom (6), Australia (11), Hong Kong (23), South } \\
\text { Africa (13), United Arab Emirates (16), Sudan (19) }\end{array}$ \\
\hline To enhance the quality of practice & 2 & United Kingdom (6), South Africa (13) \\
\hline As a career expansion & 1 & United Kingdom (6) \\
\hline To benefit the profession & 2 & United Kingdom (6), South Africa (13) \\
\hline Personal satisfaction & 2 & United Kingdom (6), Nepal (21) \\
\hline To benefit the customer/patient & 3 & United Kingdom (6), Nepal (21), Sudan (19) \\
\hline To improve sales & 2 & Nepal (21), United Arab Emirates (15) \\
\hline Strategy to overcome competition & 2 & Nepal (21), United Arab Emirates (15) \\
\hline
\end{tabular}

Table 5: Details of country which indicated barriers toward performance of extended services

\begin{tabular}{|c|c|c|}
\hline $\begin{array}{l}\text { Barriers toward performance of extended } \\
\text { services }\end{array}$ & $\begin{array}{l}\text { Total number } \\
\text { of studies }\end{array}$ & Country published (Article No.) \\
\hline Lack of pharmacist - client interaction & 6 & Jordan (9), Japan (24), Pakistan (18), Hong Kong $(23,25)$, Canada (12) \\
\hline Patients are not regular clients & 1 & Canada (12) \\
\hline $\begin{array}{l}\text { Patients do not like to be "criticized" about their } \\
\text { lifestyles }\end{array}$ & 1 & Canada (12) \\
\hline $\begin{array}{l}\text { Pharmacy practice is more toward } \\
\text { business-oriented }\end{array}$ & 7 & $\begin{array}{l}\text { Jordan (9), Japan (24), Singapore (3), Hong Kong (23), Russia (5), United } \\
\text { Arab Emirates }(14,15)\end{array}$ \\
\hline Patients are in rush and do not have time & 1 & Canada (12) \\
\hline Pharmacists are not available at pharmacies & 1 & Canada (12) \\
\hline $\begin{array}{l}\text { Pharmacy program is basically product-oriented } \\
\text { rather than patient-oriented }\end{array}$ & 1 & China (10) \\
\hline $\begin{array}{l}\text { Lack of clinical components in the pharmaceutical } \\
\text { education }\end{array}$ & 2 & Russia (5), Sudan (19) \\
\hline $\begin{array}{l}\text { No legal requirement to maintain patient } \\
\text { medication record }\end{array}$ & 1 & Jordan (9) \\
\hline \multirow[t]{2}{*}{ Lack of time } & 8 & United Kingdom (6), Australia (8), Belgium (20), Nepal (21), \\
\hline & & Netherlands (7), Singapore (3), Canada (12), United Arab Emirates (14) \\
\hline Lack of interest by pharmacy owners & 2 & Canada (12), Russia (5) \\
\hline $\begin{array}{l}\text { Lack of patient knowledge about the benefit of } \\
\text { extended services }\end{array}$ & 1 & Canada (12) \\
\hline Lack of relationship among pharmacists & 1 & Singapore (3) \\
\hline Pharmacist shortage & 4 & Australia (8), Pakistan (18), Canada (12), China (10) \\
\hline Shortage of staffs & 1 & United Arab Emirates (14) \\
\hline Obtaining financial support & 2 & United Kingdom (6), Canada (12) \\
\hline Acquiring self-confidence & 3 & United Kingdom (6), Australia (8), South Africa (13) \\
\hline Personal perception of competence & 2 & United Kingdom (6), South Africa (13) \\
\hline Pharmacists are overworked & 1 & Canada (12) \\
\hline $\begin{array}{l}\text { Lack of collaboration with other physicians or } \\
\text { other health-care professionals }\end{array}$ & 6 & $\begin{array}{l}\text { United Kingdom (6), Australia (8), Belgium (20), Singapore (3), Hong } \\
\text { Kong (23), Canada (12) }\end{array}$ \\
\hline $\begin{array}{l}\text { Inadequate management support other than } \\
\text { financial }\end{array}$ & 1 & United Kingdom (6) \\
\hline Not part of pharmacy job & 2 & Australia (8), China (10) \\
\hline Searching for a suitable area to practice & 1 & United Kingdom (6) \\
\hline $\begin{array}{l}\text { Competition with colleagues for a practicing } \\
\text { location }\end{array}$ & 1 & United Kingdom (6) \\
\hline Patient's confidence or trust issues & 6 & $\begin{array}{l}\text { United Kingdom (6), Belgium (20), Nepal (21), Hong Kong (25), United } \\
\text { Arab Emirates }(15,17)\end{array}$ \\
\hline Patient is not "open" to change & 1 & Canada $(12)$ \\
\hline Customers would not pay & 1 & Australia (8) \\
\hline
\end{tabular}


Table 5: (Continued)

\begin{tabular}{|c|c|c|}
\hline $\begin{array}{l}\text { Barriers toward performance of extended } \\
\text { services }\end{array}$ & $\begin{array}{l}\text { Total number } \\
\text { of studies }\end{array}$ & Country published (Article No.) \\
\hline Lack of reimbursement/funding for a new role & 7 & $\begin{array}{l}\text { United Kingdom (6), Australia (8), Belgium (20), Singapore (3), United } \\
\text { Arab Emirates (14), Canada (12), China (10) }\end{array}$ \\
\hline Lack of clinical tool & 2 & Canada (12), South Africa (13) \\
\hline $\begin{array}{l}\text { Lack of recognition as primary health-care } \\
\text { professional }\end{array}$ & 7 & $\begin{array}{l}\text { Pakistan (18), Singapore (3), Hong Kong }(23,25) \text {, Sudan (15), United Arab } \\
\text { Emirates }(16,17)\end{array}$ \\
\hline Lack of continuing support & 1 & United Kingdom (6) \\
\hline Lack of knowledge/skills & 11 & $\begin{array}{l}\text { Australia (8,11), Belgium (20), China (10), Pakistan (18), Nepal (21), } \\
\text { Hong Kong (23), Canada (12), Russia (5), Sudan (19), United Arab } \\
\text { Emirates (17) }\end{array}$ \\
\hline Formulating drug therapy plan & 1 & United Kingdom (6) \\
\hline $\begin{array}{l}\text { Confused perception of role by other physicians } \\
\text { and health-care professionals }\end{array}$ & 5 & $\begin{array}{l}\text { United Kingdom (6), Australia (8), Hong Kong (25), United Arab } \\
\text { Emirates (16), Sudan (19) }\end{array}$ \\
\hline Lack of ongoing training & 5 & $\begin{array}{l}\text { United Kingdom (6), Japan (24), Australia (8), Hong Kong (23), } \\
\text { Sudan (19) }\end{array}$ \\
\hline $\begin{array}{l}\text { Lack of access to sharing patient medication record } \\
\text { system, including lab-test results }\end{array}$ & 7 & $\begin{array}{l}\text { United Kingdom (6), Belgium (20), Singapore (3), Australia (8), Hong } \\
\text { Kong (23), Canada (12), Sudan (19) }\end{array}$ \\
\hline Attitudes of other health-care providers & 7 & $\begin{array}{l}\text { United Kingdom (6), Australia (11), Pakistan (18), Hong Kong (23), } \\
\text { Canada (12), United Arab Emirates }(16,17)\end{array}$ \\
\hline Lack of feedback performance & 1 & United Kingdom (6) \\
\hline $\begin{array}{l}\text { Confused among patients about the role of } \\
\text { pharmacist }\end{array}$ & 5 & United Kingdom (6), Hong Kong $(23,25)$, China (10), South Africa (13) \\
\hline Absence of counseling room & 4 & United Kingdom (6), Belgium (20), Canada (12), South Africa (13) \\
\hline No standardized practice model & 3 & Canada (12), Russia (5), United Arab Emirates (17) \\
\hline
\end{tabular}

DRP: Drug-related problem

care [34]. All these training programs can enhance CPs' knowledge, skills, and self-confidence to perform these extended services in community pharmacy settings.

In this review, it is noted that medication counseling or review is indicated as the main role of CPs, as noted in Netherlands, Russia, China, Singapore, United Arab Emirates, Sudan, Nepal, and Hong Kong $[3,5,7,10,14,17,19,21,23,25]$. This extended service is requiring for CPs to diagnose DRP among those patients who consume multiple medications and collaborate with GPs to resolve the problems. Unfortunately, lack of collaboration with GPs is noted in Singapore, Australia, Canada, Belgium, United Kingdom, and Hong Kong $[3,6,11,12,20,23]$ and it has potential to inhibit the performance of the extended service. Nevertheless, this barrier can be intervened if the local universities can add on more clinical knowledge for the undergraduate program to help them in the future to work with GPs to assess patients appropriately [35]. This working relationship between CPs and GPs can be easier if CPs have a structured and systematic approach to communicate with GPs without overruling GPs' roles [36]. For example, such structured and systematic approaches are known as WWHAM, ASMETHOD, SIT DOWN SIR, ENCORE, CHAPS-FRAPS, and Quest/SCHOLAR simple mnemonics to remember have been promoted to use as a tool to assess patients appropriately and refer the patients to GPs for further medical examination when necessary [37-42]. However, these approaches require CPs to have basic clinical knowledge before performing the assessment. It is believed that this clinical knowledge can enhance self-confidence among CPs to perform counseling services [43] in community pharmacy settings [44]. Those who would like to have an advanced clinical knowledge, they can sign up for a training program which is offered by the Board of Pharmacy Specialties (BPS) [45]. BPS offers a wide range of extended services in varies fields such as cardiology, psychiatric, geriatric, and infectious diseases [45]. However, the services are more exclusive for hospital settings rather than community settings. Hopefully, BPS can work up a training program for CPs to perform extended services in community pharmacy settings.
CPs must be given the right image as a health-care provider and they should be integrated into the health-care team to perform their knowledge and skills to fulfil patient's medication need. It is noted in the previous studies which reveal CPs can perform extended services such as referring patients to GPs [46], diabetes care [47], hyperlipidemia care [48], and conducting weight management program [49]. Such extended services can also be noted in Canada and Germany [50,51]. However, these extended services are not noted in South Africa, United Arab Emirates, Pakistan, and Sudan [13-15,18,19]. Main reason noted in the countries is the lack of clinical knowledge and skills during the undergraduate program and ongoing training afterward $[13-15,18,19]$. Therefore, it is necessary for the government, universities, consumers, pharmacy, and medical associations to sit down and discuss on how to improve the pharmacy practice through ongoing training so that the practice can give a positive impact to the society. Furthermore, it is noted in previous studies which indicate that consumers and GPs are willing to accept these extended services performed in community pharmacy settings as long as its performance can give benefit to the consumers [52,53]. Therefore, it is advisable for the universities to teach the pharmacy students about the latest clinical knowledge and skills which can help them to perform quality extended services in community pharmacy settings [52-56]. Such barriers that inhibit its performance must be noted for the future study to enhance their knowledge and skills [56-58]. Hopefully, the new generation of pharmacists can perform better-extended services in community pharmacy settings.

\section{CONCLUSION}

A clinical-based era has emerged in pharmacy practice, as responding to fulfill the demand of the society. Therefore, CPs must enhance their therapeutic knowledge and skills to perform quality extended services in community pharmacy settings. However, barriers toward its performance must be intervened. In addition, the government, consumers, pharmacy, and medical associations must have a mutual understanding about these extended services. Furthermore, these extended services are actually for the benefit of the consumers. 


\section{ACKNOWLEDGMENT}

We are grateful to those who help us to finish up this review article.

\section{REFERENCES}

1. Allen LV. A History of Pharmaceutical Compounding. Paddock Lab Inc. Vol. 11. Available from: http://www.perrigo.com/business/pdfs/ Sec\%20Artem\%2011.3.pdf.

2. Clark BE, Mount JK. Pharmacy service orientation: A measure of organizational culture in pharmacy practice sites. Res Social Adm Pharm 2006;2(1):110-28

3. George PP, Molina JA, Cheah J, Chan SC, Lim BP. The evolving role of the community pharmacist in chronic disease management-a literature review. Ann Acad Med Singapore 2010;39(11):861-7.

4. Sing WS. Pharmacy practice in Malaysia. Malays J Pharm 2001;1:2-8

5. Egorova SN, Akhmetova T. Pharmaceutical counseling: Between evidence-based medicine and profits. Int $\mathrm{J}$ Risk Saf Med 2015;27 Suppl 1:S87-8.

6. Warchal S, Brown D, Tomlin M, Portlock J. Attitudes of successful candidates of supplementary prescribing courses to their training and their extended roles. Pharm J 2006;276:348-52.

7. Ahmad A, Hugtenburg J, Welschen LM, Dekker JM, Nijpels G. Effect of medication review and cognitive behaviour treatment by community pharmacists of patients discharged from the hospital on drug related problems and compliance: Design of a randomized controlled trial. BMC Public Health 2010;10:133.

8. Berbatis CG, Sunderland VB, Joyce A, Bulsara M, Mills C. Enhanced pharmacy services, barriers and facilitators in Australia's community pharmacies: Australia's national pharmacy database project. Int J Pharm Pract 2007;15(3):185-91.

9. Malangu N. The future of community pharmacy practice in South Africa in the light of the proposed new qualification for pharmacists: Implications and challenges. Glob J Health Sci 2014;6(6):226-33.

10. Sadek MM, Elnour AA, Al Kalbani NM, Bhagavathula AS, Baraka MA, Aziz AM, et al. Community pharmacy and the extended community pharmacist practice roles: The UAE experiences. Saudi Pharm J 2016;24(5):563-570.

11. Rayes IK, Hassali MA, Abduelkarem AR. Perception of community pharmacists towards the barriers to enhanced pharmacy services in the healthcare system of Dubai: A quantitative approach. Pharm Pract (Granada) 2015;13(2):506.

12. Poudel A, Khanal S, Kadir A, Palaian S. Perception of Nepalese community pharmacists towards patient counseling and continuing pharmacy education program: A multicentric study. J Clin Diagn Res 2009;3:1408-13

13. Yamamura S, Yamamoto N, Oide S, Kitazawa S. Current state of community pharmacy in Japan: Practice, research, and future opportunities or challenges. Ann Pharmacother 2006;40:2008-14.

14. Fang Y, Yang S, Zhou S, Jiang M, Liu J. Community pharmacy practice in China: Past, present and future. Int J Clin Pharm 2013;35(4):520-8.

15. Rayes IK, Hassali MA, Abduelkarem AR. The role of pharmacists in developing countries: The current scenario in the United Arab Emirates. Saudi Pharm J 2015;23(5):470-4

16. Azhar S, Hassali MA, Ibrahim MI, Ahmad M, Masood I, Shafie AA. The role of pharmacists in developing countries: The current scenario in Pakistan. Hum Resour Health 2009;7:54.

17. Wong FY, Chan FW, You JH, Wong EL, Yeoh EK. Patient selfmanagement and pharmacist-led patient self-management in Hong Kong: A focus group study from different healthcare professionals' perspectives. BMC Health Serv Res 2011;11:121.

18. Scheerder G, De Coster I, Van Audenhove C. Pharmacists' role in depression care: A survey of attitudes, current practices, and barriers. Psychiatr Serv 2008;59(10):1155-60.

19. Wada Y, Wada Y, Ennyu S, Shimokawa KI, Ishii F. Ability of community pharmacists to promote self-care and self-medication by local residents [I]: Improvements in bone mineral density. Drug Discov Ther 2017;11(1):35-40.

20. You JH, Wong FY, Chan FW, Wong EL, Yeoh EK. Public perception on the role of community pharmacists in self-medication and self-care in Hong Kong. BMC Clin Pharmacol 2011;11:19.

21. Salim AM, Elgizoli B. Exploring self-perception of community pharmacists of their professional identity, capabilities, and role expansion. J Res Pharm Pract 2016;5(2):116-20.

22. Rayes IK, Abduelkarem AR. A qualitative study exploring physicians' perceptions on the role of community pharmacists in Dubai. Pharm Pract (Granada) 2016;14(3):738
23. Al-Wazaify M, Albsoul-Younes A. Pharmacy in Jordan. Am J Health Syst Pharm 2005;62(23):2548-51.

24. Laliberté MC, Perreault S, Damestoy N, Lalonde L. Ideal and actual involvement of community pharmacists in health promotion and prevention: A cross-sectional study in Quebec, Canada. BMC Public Health 2012;12:192.

25. Hoti K, Hughes J, Sunderland B. An expanded prescribing role for pharmacists-an Australian perspective. Australas Med J 2011;4(4):236-42.

26. Dennis S, May J, Perkins D, Zwar N, Sibbald B, Hasan I. What evidence is there to support skill mix changes between GPs, pharmacists and practice nurses in the care of elderly people living in the community? Aust N Z Health Policy 2009;6:23.

27. Roberts AS, Benrimoj SI, Chen TF, Williams KA, Aslani P. Practice change in community pharmacy: Quantification of facilitators. Ann Pharmacother 2008;42:861-8.

28. Gray A, Suleman F. Training for clinical pharmacists: Plat du jour or smorgasbord? S Afr Pharm J 2012;79(2):38-40.

29. Christensen DB, Farris KB. Pharmaceutical care in community pharmacies: Practice and research in the US. Ann Pharmacother 2006;40(7-8):1400-6.

30. Smailhodzic E, Hooijsma W, Boonstra A, Langley DJ. Social media use in healthcare: A systematic review of effects on patients and on their relationship with healthcare professionals. BMC Health Serv Res 2016; $16: 442$

31. Ventola CL. Social media and health care professionals: Benefits, risks, and best practices. Pharm Ther 2014;39(7):491-520.

32. Kristina SA, Thavorncharoensap M, Pongcharoensuk P, Prabandari YS. Impact of smoking cessation training for community pharmacists in Indonesia. Asian Pac J Cancer Prev 2015;16(8):3319-23.

33. Noyce PR. Providing patient care through community pharmacies in the UK: Policy, practice, and research. Ann Pharmacother 2007;41(5):861-8

34. Bajorek BV, Lemay KS, Magin PJ, Roberts C, Krass I, Armour CL. Preparing pharmacists to deliver a targeted service in hypertension management: Evaluation of an interprofessional training program. BMC Med Educ 2015;15:157.

35. Bugnon O, Hugentobler-Hampaï D, Berger J, Schneider MP. New roles for community pharmacists in modern health care systems: A challenge for pharmacy education and research. Chimia (Aarau) 2012;66(5):304-7.

36. Chui MA, Stone JA, Odukoya OK, Maxwell L. Facilitating collaboration between pharmacists and physicians using an iterative interview process. J Am Pharm Assoc 2014;54:35-41.

37. Blenkinsopp A, Paxton P, Blenkinsopp J. Symptoms in the Pharmacy: A Guide to the Management of Common Illness. $5^{\text {th }}$ ed. Oxford, UK: Blackwell Publishing; 2005. p. 1-13.

38. Edwards C, Stillman P. Minor Illness or Major Disease? The Clinical Pharmacist in the Community. $4^{\text {th }}$ ed. London: Pharmaceutical Press; 2006. p. 1-10.

39. Rutter P. Community Pharmacy: Symptoms, Diagnosis and Treatment. Edinburgh: Churchill Livingstone, An Imprint of Elsevier Limited; 2004. p. 9-11.

40. Rutter PM, Horsley E, Brown DT. Evaluation of community pharmacists' recommendations to standardized patient scenarios. Ann Pharmacother 2004;38(6):1080-5.

41. McCallian DJ, Cheigh NH. The pharmacist's role in self-care. J Am Pharm Assoc (Wash) 2002;42 5 Suppl 1:S40-1.

42. Buring SM, Kirby J, Conrad WF. A structured approach for teaching students to counsel self-care patients. Am J Pharm Educ 2007;71(1):8.

43. Hu JH. Integrated Pharmaceutical Care. $1^{\text {st }}$ ed. Shanghai: The Second Military Medical University Press; 2001

44. Editorial Board. Temporary regulations of pharmacy administration for medical institutions. Chin Hosp Pharm J 2002;4:2-7.

45. BPS. Board of Pharmacy Specialities. Available from: http://www. bpsweb.org.

46. Taylor JG, Joubert R. Pharmacist-led minor ailment programs: A Canadian perspective. Int J Gen Med 2016;9:291-302.

47. Mehuys E, Van Bortel L, De Bolle L, Van Tongelen I, Annemans L, Remon JP, et al. Effectiveness of a community pharmacist intervention in diabetes care: A randomized controlled trial. J Clin Pharm Ther 2011;36(5):602-13

48. Nola KM, Gourley DR, Portner TS, Gourley GK, Solomon DK, Elam M, et al. Clinical and humanistic outcomes of a lipid management program in the community pharmacy setting. J Am Pharm Assoc (Wash) 2000;40(2):166-73

49. Morrison D, McLoone P, Brosnahan N, McCombie L, Smith A, 
Gordon J. A community pharmacy weight management programme: An evaluation of effectiveness. BMC Public Health 2013;13:282.

50. Eickhoff C, Schulz M. Pharmaceutical care in community pharmacies: Practice and research in Germany. Ann Pharmacother 2006;40(4):729-35.

51. Krass I, Armour CL, Mitchell B, Brillant M, Dienaar R, Hughes J, et al. The pharmacy diabetes care program: Assessment of a community pharmacy diabetes service model in Australia. Diabet Med 2007;24(6):677-83.

52. Kamei M, Teshima K, Fukushima N, Nakamura T. Investigation of patients' demand for community pharmacies: Relationship between pharmacy services and patient satisfaction. Yakugaku Zasshi 2001;121(3):215-20

53. Waszyk-Nowaczyk M, Nowaczyk P, Simon M. Physicians' and patients' valuation of pharmaceutical care implementation in Poznan
(Poland) community pharmacies. Saudi Pharm J 2014;22(6):537-44.

54. Snyder ME, Zillich AJ, Primack BA, Rice KR, Somma McGivney MA, Pringle JL, et al. Exploring successful community pharmacist-physician collaborative working relationships using mixed methods. Res Social Adm Pharm 2010;6(4):307-23.

55. Sarriff A, Nordin N, Hassali MA. STARZ-DRP: A step by step approach for pharmacy triage services. Malays J Pharm 2011;1(9):311-26.

56. Detoni KB, do Nascimento MM, Oliveira IV, Alves MR, Gonzales MM, Ramalho-De-Oliveira D. Comprehensive medication management services in a Brazilian specialty pharmacy: A qualitative assessment. Int J Pharm Pharm Sci 2017;9(3):227-32.

57. Nasution A, Syed Sulaiman SA, Shafie AA. Pharmacists' perception of their role and assessment of clinical pharmacy education to improve clinical pharmacy services in Indonesian hospitals. Int J Pharm Pharm Sci 2014;6(11):177-80. 